\title{
Learning from the Past: Trends in Executive Compensation over the Twentieth Century
}

\author{
CAROLA FRYDMAN
}

CESIFo Working PAPER No. 2460

CATEGORY 4: LABOUR MARKETS

NOVEMBER 2008

Presented at CESifo Venice Summer Institute 2008, Workshop on EXeCutive Pay

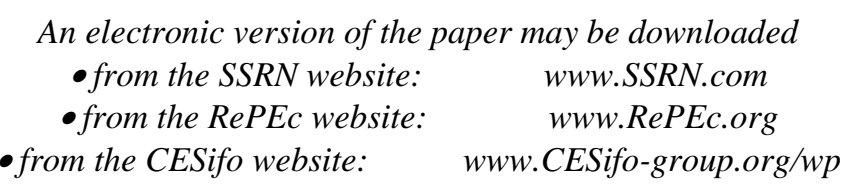




\title{
Learning from the Past: Trends in Executive Compensation over the Twentieth Century
}

\begin{abstract}
In recent years, a large academic debate has tried to explain the rapid rise in CEO pay experienced over the past three decades. In this article, I review the main proposed theories, which span views of compensation as the result of a competitive labor market for executives to theories based on excess of managerial power. Some of these hypotheses have found support in cross-sectional evidence, but it has proven more difficult to determine which factors have caused the observed changes in pay over time. An alternative strategy is to evaluate the fit of plausible explanations out of sample by contrasting them with the evolution in executive pay and the market for managers during earlier time periods. A case study of General Electric suggests that evidence for earlier decades can speak to the recent trends and reveals the limitations of current explanations to address the long-run data.
\end{abstract}

JEL Code: J33, M52, N32.

Keywords: executive compensation, managerial incentives, corporate governance, market for managers.

\author{
Carola Frydman \\ MIT Sloan School of Management \\ 50 Memorial Drive, Room E52-436 \\ Cambridge MA, 02142 \\ USA \\ frydman@mit.edu
}

I thank the participants at the CESifo Venice Summer Institute Workshop on "Executive Pay" held on July, 16-17, 2008 for their comments. 


\section{Learning from the Past: Trends in Executive Compensation over the Twentieth Century}

\section{Introduction}

As the main decision makers in large public corporations, top executives comprise an important albeit small part of the labor force. Thus, the compensation of these individuals is of special interest because it influences their decision-making process. Since the 1980s, the academic research on executive pay has grown significantly (Murphy 1999). This new interest on the topic is probably related to two main reasons. First, the level of executive compensation has soared since the 1970s, due in part to the increasing use of employee stock options (Murphy 1999, Hall and Liebman 1998). In consequence, both the high levels of pay and the structure of compensation have become under intense scrutiny. Second, comprehensive datasets with detailed information on the compensation of top managers are available for this period, allowing a precise determination of the stylized facts on pay over the past three decades.

The recent trends in executive pay have generated a considerable debate on the determinants of compensation. Proposed theories cover a wide spectrum, ranging from viewing the level of pay as the efficient outcome from a competitive labor market for managers to arguing that extremely high pay is the result of managers inefficiently extracting rents from the firms they manage. While some of the proposed hypotheses have found support in cross-sectional evidence, it has proven more difficult to tease out the drivers of pay over time. Since the 1970s, the level of executive pay has exhibited a steady upward trend. The potential determinants of pay suggested by most of these theories have also changed mostly monotonically during this period, leading to a 
systematic correlation between these variables and executive pay. Thus, it is difficult to disentangle which of the proposed explanations has mattered in a more causal manner focusing only on evidence for recent years.

An alternative strategy consists in verifying the predictions of various theories by using data for other countries or other time periods. A substantial literature has established how compensation practices vary across countries and is now starting to evaluate different theories on pay using these data. ${ }^{1}$ Information on managerial pay from other periods in U.S. history is also a valuable addition because other periods provide more variation in the trends in pay and in the determinants to be assessed with arguably less variation in institutions than in cross-country studies. Frydman and Saks (2008) provide such a study by setting forth the long-run changes in compensation in a systematic manner and quantitatively analyzing the contribution of several explanations to the trends in pay over time. In this article, I build on that work by focusing on the evolution of compensation and managerial backgrounds of the top executives of General Electric. This qualitative case study addresses a larger set of theories for the recent changes in pay and provides a more involved view on the uses of historical data than was possible in Frydman and Saks (2008).

The lead explanations for the recent rise on executive pay can be broadly divided into two categories. First, a set of theories view compensation as the competitive outcome from the labor and product markets. These explanations encompass the role of demand for talent and scale effects; increase in the demand for generalist CEOs; the effects of trade and product market competition; and the emergence of alternative outside

\footnotetext{
${ }^{1}$ See, for example, Llense (2008) for an application of the Gabaix and Landier (2008) model to French data.
} 
options for managers. A second set of theories emphasizes the constraints that institutions, either within or outside corporations, impose on executive pay. The main hypotheses in this group include managers' ability to extract rents from firms with weak corporate governance; the monitoring performed by large shareholders; the effects of peer benchmarking; and the role of social norms. I summarize these explanations, making an emphasis on the limitations that each one has in accounting for the changes in compensation over time using only data for the last three decades.

While earlier data provide an alternative "laboratory" to analyze the different theories on executive compensation, a potential concern is that the organization of firms has evolved significantly over time. However, the experience of public corporations during earlier decades is relevant for the policies implemented in recent years. The role of top managers has not changed significantly since the separation of corporate ownership from corporate control at the turn of the twentieth century (Berle and Means 1991, Chandler 1977). Thus, the main issues concerned with the remuneration of corporate executives have been prevalent over the longer run.

To provide an involved view of the changes and challenges experienced by firms over the longer run, I review the experience of General Electric. The history of this successful corporation serves to illustrate a significant evolution in the compensation and the labor market for top managers over time. Relative to the evidence for the past three decades, the level of pay of GE's executives was significantly lower and grew at a slower rate from the 1940s to the 1970s. ${ }^{2}$ The characteristics of GE's managers have also changed, from the executives having education mostly in engineering or law earlier in the

\footnotetext{
2 This pattern in the evolution of compensation for GE's top managers is similar to the trend in pay of the larger sample of firms analyzed in Frydman and Saks (2008).
} 
century to a more diverse educational background since the 1960s. Moreover, recent managers have worked in different sectors of the firm, potentially acquiring skills that are more general in nature. The acquisition of general human capital may have allowed internal candidates for the CEO position to leave the firm for corporations in different industries when passed up for the chief executive job.

Since the trends for GE are not unique to this corporation, the historical evidence suggests that assessing the mechanisms that determine executive pay is still an important challenge. Most of the proposed theories for the recent decades do not seem to fit well with the data on compensation and the characteristics of managers prior to the 1970 s. Thus, future work on executive compensation can learn from the past to further our understanding of the present.

2. The current debate on the determinants of the growth in executive pay Many different theories have been proposed to explain the recent rise in CEO pay. While difficult to categorize them, these explanations can broadly be divided as theories that view the level of executive pay as a result of competitive forces in the labor and product markets and theories that argue that institutions either within or outside the firm influence the level of pay. I summarize the most popular explanations within these two groups and assess their limitations for explaining the evolution of executive compensation over time.

\subsection{Competition and executive compensation}

2.1.a Demand for talent and scale effects 
In recent years, the view that executive pay is the response to supply and demand forces within a competitive labor market for executives has gathered increasing support. Models such as Rosen (1981 and 1982) propose that competition for scarce managerial talent leads to relative higher level of pay in larger firms in a given year. The marginal product of CEO's effort is higher in larger firms because the ability of the chief executive trickles down more hierarchical layers. Consequently, competition leads to positive assortative matching between managerial ability and firm size.

More recently, this idea has been adapted to explain the growth in compensation over time (Tervio 2008). Within this framework, Gabaix and Landier (2008) argue that changes in the level compensation over time should be determined by the growth in the size of the typical firm in the economy. Indeed, they find a one-to-one correlation between CEO pay and the market capitalization of the median firm among the largest 500 since the 1970s. According to their view, an increase in the scale of firms completely explains the growth in CEO pay over time.

The assessment of this theory presents two main empirical challenges. First, a correlation between the level of CEO compensation and median firm size does not imply a causal relationship between these two measures. Moreover, the documented empirical relationship does not establish that the underlying mechanism generating this correlation is actually caused by the assignment of scarce managerial talent to firms in a competitive market.

2.1.b Changes in the types of managerial skills 
A related view that also relies on a competitive labor market for executives argues that the increase in compensation is related to a shift in the type of skills that firms demand, from firm-specific human capital to general managerial skills (Murphy and Zábojník 2004). This theory predicts that, as general skills become relatively more important, average pay increases, more CEOs are hired from outside the firm, and the disparity between CEO pay and other top executives at the corporation increases (Murphy and Zábojník 2004, Frydman 2006).

An advantage of this explanation is that it matches well with the rising mobility of executives experienced in recent decades. While only 15 percent of new CEO appointments were hired from outside the firm in the 1970s, almost 33 percent of the chief executives selected from 2000 to 2005 were outsiders (Murphy and Zábojník 2007). However, a main challenge for this theory is to quantify managerial skills. Moreover, changes in the demand for skills, which is most likely related to the production function of firms, probably occurred slowly over time.

\section{1.c Trade and product market competition}

Because labor markets receive a negative signal on managerial quality when firm performance suffers, competition in the product market may serve as an alternative mechanism to explicit wage contracts in the disciplining of managers (Fama 1980). However, recent research argues instead that higher-powered incentives are needed when product markets are more competitive. In periods of globalization, technological innovation, and deregulation, the complexity of the responsibilities of top management increases, thereby increasing the demand for talented executives. Thus, higher 
performance pay is required to attract and provide incentives to top managers. Because a higher level of pay is needed to compensate risk-averse executives for the extra risk added by incentives, the recent growth in pay may be the result of more product market competition.

An advantage of this explanation is that allows for a cleaner identification strategy than most other theories on executive pay. For example, Cuñat and Guadalupe (2006) find that the sensitivity of pay to firm performance, the inequality among top managers within the firm, and the probability of turnover increase when competition (measured by import penetration) becomes more pronounced. Moreover, pay-performance sensitivities also increase when industries deregulate (Hubbard and Palia 1995, Cuñat and Guadalupe 2004). Although exogenous shocks to competition provide a valuable identification strategy, this methodology is more useful for identifying effects of competition on payto-performance than on the level of pay. Moreover, a trade-off of using a precise strategy is that it allows for identifying only very particular aspects of competition. Thus, a large fraction of the variation in pay over time remains unexplained within this framework.

\section{1.d The rise of finance and outside options for corporate managers}

In most models proposing a competitive labor market for executive, the level of pay is positively associated with the outside option of top managers. Thus, the recent rise in executive pay could be related to an increase in the reward that CEOs can obtain in alternative activities. In recent decades, the opportunities and the gains in the financial sector have developed dramatically (Kaplan and Rauh 2007). Thus, the increase in CEO 
pay may be an equilibrium effect if highly paid jobs in finance are a plausible alternative for top managers.

For this argument to hold, close substitution between the skills to become a successful leader in large public companies and in the financial sector is a key assumption. However, little is known about the relevant labor market for CEOs and other top executives. The supply of executives and the alternative jobs that these individuals could engage is largely unknown, making it extremely difficult to quantitatively assess this hypothesis.

\subsection{Institutional factors inside and outside the firm}

\section{2.a Corporate governance and extraction of rents}

A large literature has suggested that the high level in executive compensation is the result of CEOs ability to extract rents from the firm (Bebchuk and Fried 2003 and 2004). When firms' boards of directors are not strong to limit the power of CEOs, chief executives acting in a self-interested manner will skim the firm. According to this view, the level of executive pay is excessive and inefficient. Moreover, proponents of this view argue that the structure of pay is also the result of poor corporate governance, as entrenched executives find it easier to reward themselves with lavish paychecks in forms of compensation that are less observable or harder to value, as employee stock options, pensions, perquisites and severance payments.

Given some highly publicized cases of managerial power leading to outrageous compensation packages, this hypothesis has some merit. Moreover, differences in corporate governance seem to influence the specific behavior of executive pay. For 
example, CEOs in firms with weak boards are rewarded for lucky events that increase firm value but that are independent of their actions. However, chief executives also receive hefty paychecks in firms with strong governance with the intent to provide incentives (Bertrand and Mullainathan 2001). Thus, managerial skimming may be the correct explanation for the level of compensation in a few firms, but it is less obvious whether this theory can account for the changes in the median level of pay.

While rent extraction may help explain some of the variation in pay in the crosssection, it is more unlikely that the trend in pay over time is due to governance practices. A steady worsening in the corporate governance of U.S. corporations may help explain the explosion in pay and in stock option use since the 1980s, but most available proxies for governance show no deterioration over this period. ${ }^{3}$ Moreover, even a correlation between governance measures and the level or structure of pay does not imply that the relationship between these variables is causal. Since the governance structure is an endogenous choice of corporations, identifying causality is particularly difficult in this context.

\section{2.b Direct monitoring of large shareholders}

Although high levels of pay are usually linked to poor corporate governance, an alternative view claims that this trend could actually be associated with improvements in governance. As corporate governance improves, boards become more diligent and independent. As a consequence, boards are more likely to fire underperforming CEOs who will be less able to become entrenched. Thus, the increase in CEO pay could be a

\footnotetext{
${ }^{3}$ For example, a comprehensive index based on corporate governance provisions and state laws indicates no change in shareholders' rights for the median or average firm among 1500 large corporations over the 1990s (Gompers, Ishii and Metrick 2003).
} 
response to the decline in job stability faced by top managers as boards' monitoring ability develops (Hermalin 2005).

Several pieces of evidence are consistent with this hypothesis. The stability of top management positions has deteriorated, as indicated by the rising likelihood of forced turnover since the 1970s (Huson, Parrino, and Starks 2001) and the decline in CEO tenure since the mid-1990s (Kaplan and Minton 2006). Moreover, boards' ability to monitor CEOs has likely improved in recent years. ${ }^{4}$ However, arguments similar to those made in Section 2.2.b highlight the difficulties of empirically evaluating this theory with available data.

\section{2.c Peer benchmarking}

Most corporations set CEO pay using as a benchmark the compensation at a peer group composed of similar companies. The practice of competitive benchmarking is regarded as generating a ratchet effect that leads to continuous growth in the level of pay (Murphy 1999). To signal to the market that the incumbent CEO is of high-quality, firms award their chief executives a level of compensation above median pay in their relevant peer group. ${ }^{5}$ If boards compensation in this manner, the median level of pay increases every year independent of the performance of the firm, leading to excessively high remuneration.

Arguably, the role of compensation consultants in the determination of CEO pay has increased since the 1970s (Khurana 2002). However, this fact alone does not validate

\footnotetext{
${ }^{4}$ For example, the presence of independent directors at boards has increased over time (Lehn, Patro, and Zhao 2003).

${ }^{5}$ A pay level below the $50^{\text {th }}$ percentile is often labeled "below market," perhaps providing a negative signal to the market.
} 
peer benchmarking as a major force in the growth of compensation. Indeed, Bizjak, Lemmon and Naveen (2008) suggest that the practice of peer benchmarking may be an efficient way to determine the value of a CEO in a competitive market and retain managerial talent. In particular, they find that peer-group benchmarking is more correlated to economic factors (measured by the labor market conditions and firm performance) than to the corporate governance of firms.

\section{2.d Social norms}

The growth in top management pay experienced in the U.S. since the 1970s happened concurrently with a pronounced increase in income inequality. The disparity in pay was driven mostly by an expansion in income levels at the top of the distribution (Piketty and Saez 2003). Thus, it is possible that the factors driving these two phenomena are related. I analyzed two of the main hypothesis for the change in income inequality (trade and skilled-biased technical change) and their relevance for executive pay in Section 2.1. However, a third main factor to be considered is changes in social norms. According to this view, the rise in income inequality in the past three decades is a consequence of the removal of social norms that constrained the level of pay (Piketty and Saez 2003, Levy and Temin 2007).

A limitation of this hypothesis is that social norms are not easily quantifiable, making it difficult to assess the importance of this explanation empirically. Thus, the relevance of social norms for the trends in executive compensation is difficult to validate or disprove. 
3. Learning from the past: executive compensation as a longer-run concern In a cross-section of firms, it is possible to obtain evidence supporting many of the theories discussed in Section 2. However, most of these arguments rely on measures that have changed monotonically over time since the 1970s. Because executive pay was mostly trending upwards during this period, there is little evidence on a causal relationship between each of the relevant variables and the changes in compensation over time. Thus, as argued in more detail by Frydman and Saks (2008), far less is known about the determinants for the time-series of executive pay.

To better understand the mechanisms responsible for the level and structure of pay over time, a viable channel is to look for alternative sources of variation to evaluate the validity of each theory out of sample. One plausible source is to focus on an earlier time period, when the changes in executive compensation were considerably different. This exercise is relevant because, as I argue in Section 3.1, the compensation of top executives has been a main problem for corporations ever since the separation of corporate ownership from corporate control during the beginning of the twentieth century (Berle and Means 1991). Moreover, I show in the next section that analyzing executive pay during earlier decades is possible because systematic data on the remuneration of top managers is available since the mid-1930s.

\subsection{Earlier evidence on managerial pay}


In the early $20^{\text {th }}$ century compensation practices were closely guarded secrets and consequently only scattered historical evidence exists on executive salaries. ${ }^{6}$ Revelations regarding executive pay first occurred during World War I, when railroad corporations became managed by the federal government and the exorbitant salaries of railroad officers were exposed. Public scrutiny intensified during the 1920s, when the compensation of railroad and banking executives were published in the popular press. ${ }^{7}$

By the early 1930s, the controversy surrounding the level of pay had extended to executives in all businesses. As the economy slipped into the Depression, the nation became increasingly troubled by the "lavish stipends and bonuses" accruing to the managers of large public corporations. ${ }^{8}$ Prompted by these concerns, the Reconstruction Finance Corporation, the Federal Trade Commission, and several other institutions requested information on the compensation of officials in firms under their respective jurisdictions. ${ }^{9}$ These dispersed efforts to monitor the compensation practices of major corporations were centralized with the establishment of the Securities and Exchange Commission (SEC) in 1934.

Created to enforce the Securities Exchange Act of 1934, the SEC was put in charge of the disclosure of data by firms participating in the securities market, thereby regulating corporate finance (Seligman 2003). Disclosure of information related to the

\footnotetext{
${ }^{6}$ Court records are a possible source of information for this period, because they occasionally reveal the remuneration of corporate officers (Baker, 1938). Alternatively, one could rely on payroll records from individual firms.

${ }^{7}$ See, for example, "Explains Big Salary of Railroad Head. Charles Frederick Carter Says Competent President Earns it Many Times," New York Times, December 24, 1922; "Comptroller Seeks Salary Data From National Banks," Wall Street Journal, February 25, 1921; "Commerce Commission Goes Into Executives' Salaries,” Wall Street Journal, December 23, 1922; “They Earn Their Salaries,” Wall Street Journal, February 27, 1923.

8 "Inquiry Into High Salaries Pressed by the Government," New York Times, October 29, 1933.

${ }^{9}$ For example, the Federal Trade Commission was directed to collect information on the salaries of executives from the companies listed in the NYSE in 1933 (Senate Resolution No. 75, Seventy-third Congress).
} 
remuneration of executive officers and directors was intended to deter managers from engaging in wrongful behavior and mismanaging corporate assets (Loss and Seligman 1995). Thus, the inception of the SEC has made executive compensation data through $10-\mathrm{K}$ reports and proxy statements available to the public from the 1930s to the present.

These data have been used by researchers to analyze executive compensation at several points in time and, more recently, systematically by Frydman and Saks (2008), providing a consistent view of how compensation evolved over the longer run. Thus, the theories proposed to explain evolution of pay over the past thirty should be contrasted against the now well-established facts on executive compensation over most of the twentieth century.

\subsection{A case study of executive compensation at General Electric}

To provide a more involved view of the changes in compensation policies and in the labor market for managers over time, I use the history of General Electric Corporation (GE) as an illustration. This corporation is a primary example of corporate and technological success of the twentieth century. ${ }^{10}$

\section{2.a Brief history of General Electric}

GE was constituted as a firm that operated in the electrification business in 1892 when Edison Electric Light Company, founded by Thomas Edison only two years earlier, merged with its competitor Thomas-Houston Electric Company. Over time, and as many

\footnotetext{
${ }^{10}$ For example, GE is the only firm of the original twelve companies that constituted the Dow Jones Industrial Index in 1896 still belonging to it. Moreover, when Irving Langmuir won the Nobel Prize in Chemistry in 1932, he became the first individual to receive such award for research performed outside an academic institution.
} 
other large successful firms in the economy, the business of GE evolved, mostly prompted by savvy managers that were able to anticipate future challenges. The first stage of diversification came early in the twentieth century. With the establishment of GE Labs, the pinnacle of scientific research within a corporation at that time, the company expanded into the manufacturing of transformers (1903), radio technology (1920s), and silicone and nuclear power (1940s). The 1960s and 1970s were a period of diversification and GE was no exception, growing into sectors as diverse as aerospace, computers, and mining. As may other firms becoming large conglomerates at that time, this fast growth came without significant improvements in stock market performance. Thus, the following two decades saw a refocus of the corporate strategy, with a switch from manufacturing to technology and (mainly financial) services as well as increasing the presence of the company abroad. The company has changed its focus again in the past decade, by diminishing the reliance on financial services and mature industrial businesses, expanding instead into healthcare and entertainment.

\section{2.b Top management at General Electric and the market for managers}

Over the many challenges faced throughout its history, only nine chief executives led GE. These individuals had, in general, a fairly long tenure as chief executives; with the shortest tenure lasting five years while three CEOs remained at the position for at least twenty years. GE's managerial talent has always been groomed within the firm: excluding the early CEOs who joined the firm when it was founded, Jeff Immelt had the shortest tenure at the firm (a total of 18 years) among these nine individuals when he was appointed CEO in 2001. 
The educational and career background of GE's top managers is indicative of a broader trend in the market for executives. Up to the late 1950s, almost all of GE's CEOs had a college education and had specialized in either engineering or law. Depending on this background, they had mainly worked their way up either in production or in the legal department before moving into general management. The education of chief executives became more varied since the 1960s, a fact that is also evidenced at GE: in the past four decades, these individuals had degrees in economics, engineering, or mathematics. Moreover, Immelt is the first CEO at GE to hold an MBA degree, reflecting the growing importance of business education in the careers of top managers more generally.

As revealed by the available biographical information, the work experience of top managers had also evolved considerably. Prior to the 1970s, most top managers worked mainly in one sector of the firm (as production, finance, or the legal department) throughout their entire career. Since then, a broader experience has become more important, perhaps because top managers are now required to lead corporations that are more diversified in nature. As a consequence, many firms established programs to rotate promising managers across different sectors. For example, Reginald H. Jones, GE’s CEO from 1972 to 1981, worked as a manager in consumer, utility, industrial, construction, and distribution fields after being assigned into general management, before becoming the chief financial officer of the corporation in 1968. Thus, he plausibly acquired skills in several different areas of the firm that contributed to his success as a chief executive of a widely diversified corporation. 


\section{2.c Executive compensation at General Electric}

GE has been one of the best performers throughout the entire twentieth century, but the trends in the level and structure of compensation for its top executives are fairly representative of most large publicly traded corporations. ${ }^{11}$ The remuneration of the three-highest paid officers at GE was entirely composed by salaries and current bonuses (bonuses in either cash or stock, both awarded and paid out in the given year) prior to the 1950s. ${ }^{12}$ Perhaps prompted by extremely high labor income tax rates, forms of compensation more directly tied to the performance of the firm started being used at midcentury. Since the 1950s, deferred bonuses tied to firm and, on occasion, to individual performance gained importance. ${ }^{13}$ Perhaps more surprising is that employee stock options became frequently used to remunerate "key employees" over this period (see Figure 1).

As many other firms in the 1950s, GE established its first stock option plan in 1953. While high taxes on labor income reduced the attractiveness of cash compensation, options had a considerable tax advantage since the 1950s. The 1950 Revenue Act determined that, by satisfying a series of qualifications, "restricted" stock options could be taxed at the much lower rate on capital gains. When introducing the new plan, GE’ management argued to their shareholders;

Since $[\ldots]$ the Internal Revenue Code amendment in 1950 [...] over 200 companies whose stock is listed on the NYSE, including many

\footnotetext{
${ }^{11}$ See Frydman and Saks (2008) for comparison to more representative trends based on a large sample of firms.

${ }^{12}$ Data on executive compensation was collected from GE's proxy statements for several years. Because evidence for a single firm is intrinsically fairly noisy, the trends in pay are calculated using a three-year moving average for the compensation of GE's three highest-paid officers.

${ }^{13}$ In the case of GE, these bonuses were mainly paid out after the executives had retired. However, many other large firms established incentive compensation plans that awarded bonuses to be paid out in cash or in stock over a number of years (Frydman and Saks 2008).
} 
competitors of your Company, have adopted stock option plans ...

[Such a plan] is essential if the Company is to compete successfully with other companies for the services of individuals of outstanding ability and accomplishment.

General Electric’ Proxy Statement, March 20 ${ }^{\text {th }}, 1953$

GE's proxy statement suggests that, by helping the firm to get around prohibitive taxation, stock options allowed the firm to compete for managerial talent, although they accounted for a small fraction of total pay at that time (see Figure 1). More importantly, corporations were aware of its competitors' compensation policies and, probably, of the level of remuneration awarded to other top executives even during this period. Thus, the market for managers and, in particular, their compensation may have been more integrated during earlier decades than previously thought.

The evolution of the total real level of pay for GE's three highest-paid executives indicates that there were two distinct periods in remuneration policies. First, the total real level of pay for GE's top three managers increased at a slow rate of about two percent per year from the 1940s to the 1960s. This period of little growth was followed by a rapid acceleration in top management pay, mostly encouraged by the increasing use of stock options since the 1980s and of restricted stock since the 1990s. From the 1970s to the present, the compensation of the three highest-paid officers at GE has grown at the significantly higher annual rate of eight percent. Executive compensation behaved in a different manner in the past, generating a different relationship between executive compensation and several of the proposed determinants for the recent increase in pay 
over the earlier decades. Thus, historical evidence presents a challenge to some of the main explanations discussed in Section 2.

\section{2.d Generalizing the findings}

Focusing on a particular company allows revealing both general trends as well as emphasizing that the experiences of particular firms and managers are, to a large extent, idiosyncratic. However, it is important to relate the evidence for GE to more general, stylized facts on compensation and managerial careers that have been put forth by the existing literature. Moreover, new long-run facts can be used to illuminate the current debate on the drivers of executive pay.

A main contribution of analyzing executive pay during earlier periods is that the long-run trends provide significant variation in the level of compensation over time. Most of the debate on managerial pay has focused on finding theories that can explain a steady and rapid increase in CEO compensation. However, the evidence from GE discussed here and, for a more comprehensive set of firms, in Frydman and Saks (2008), shows a significantly different pattern during earlier decades. Following World War II, executive pay remained fairly constant for almost three decades. This is surprising relative to current evidence because the governance of corporations was arguably weaker, the ownership of firms was more dispersed than in recent years, and firms were also growing and becoming more complex during this earlier period. Moreover, anecdotal evidence from GE and other corporations suggests that firms were aware of and took the compensation strategies of competitors into account when determining the pay of their 
top managers, at least since the disclosure of pay data started being required by the SEC in the 1930s.

It is difficult to argue that the competition in product markets did not increase as well during the 1950s and 1960s, a period of little change in executive compensation. However, trade and globalization may have affected firms at the end of this period in a more direct manner, by affecting the tasks that executives were responsible for and, consequently, the market for managers more broadly. ${ }^{14}$ The history of GE is indicative of an important transformation in the market for top managers. Once large corporations were relatively mature by the 1950s and 1960s, the market for top managerial talent took place mostly within the organization. These "organization men" rose through the ranks of the firm, most often than not working their way up in one particular area of the firm (usually in production or in the legal department) (Whyte 1956). Managerial skills seem to have been mostly firm-specific; top executives usually had an educational background in science or engineering, were exposed to a single area of the firm before becoming general managers, spent most of their career at the same corporation, and rarely moved to a different firm late in their career (even when passed up for the chief executive position).

The slow but steady growth in the importance of business education and the increasing diverse sectoral experience of managers indicate that managerial skills have are become more general in nature since mid-century. Moreover, as discussed in Section 2.1.b, the likelihood of selecting an outsider for the CEO position has more than doubled

\footnotetext{
${ }^{14}$ Anecdotal evidence suggests that a shift in the demand for managerial skills occurred as firms evolved during the 1950s and 1960s due to globalization, competition, and increases in the complexity of large corporations. For example, Packard (1962) emphasizes that "Both the competition and the new markets that European unity promises - plus the need of U.S. companies to expand significantly to develop world markets - call for new imaginative kinds of business leadership. [...] There is grave doubt that America industry has been developing enough of the kind of leaders who will be competent to guide their enterprises effectively in this new environment.”
} 
in the past three decades. However, many firms (as GE, for example) still maintain a policy of forming and recruiting its own top managerial talent within the organization. But even in those firms, the behavior of the market for managers indicates that the mobility of executives across industries and organizations has increased. When GE selected Jeff Immelt in 2001 for the CEO position, W. James Mc Nerney Jr. and Robert L. Nardelli, the two contenders from the firm that were passed up for the job, quickly left to become CEOs in firms as different from GE as 3M and Home Depot, respectively. The responsibilities of top executives appear to have evolved over time, arguably from tasks requiring mostly firm-specific skills to decisions based on general human capital that could be applied in diverse firms. However, the pace and magnitude of these changes suggest a relatively minor role of a shift in the types of managerial skills on the long-run evolution in compensation (Gabaix and Landier 2008, Kaplan and Rauh 2007).

In sum, earlier data provides a new environment in which to contrast the main theories for the recent rise in CEO pay. ${ }^{15}$ Available evidence suggests that the proposed explanations do not fit well with the long-run trends, raising new challenges to provide an understanding of the evolution of executive compensation and the labor market for corporate managers.

\section{Conclusion}

In this article, I argue that the lack of consensus on the determinants for the recent increase in CEO and other top management pay is in part associated with the use of quantitative evidence that is limited to the past three decades. Because the changes in

\footnotetext{
${ }^{15}$ Two remaining theories, the importance of social norms and outside opportunities for managers, are hard to assess empirically because it difficult to construct relevant proxies.
} 
compensation have been fairly monotonic over this period, an understanding of the timeseries evolution of pay has been limited.

An alternative strategy to better grasp the mechanisms that affect executive compensation is to learn from the past by assessing the main proposed theories using data for other countries or other time periods. In particular, the disclosure of compensation for publicly traded corporations allows this exercise for U.S. firms since the 1930s. These historical data reveal a complex picture of the evolution of managerial pay and the market for managers. Moreover, most of the common explanations for the recent changes in compensation cannot individually account for its evolution over the long run. To match the trends suggested by the quantitative and anecdotal evidence for the twentieth century, future research should evaluate new views of the determinants of pay as well as address how the relevant explanations have changed over time. 


\section{References}

Bebchuk, Lucian A., and Jesse M. Fried. 2003. "Executive Compensation as an Agency Problem,” Journal of Economic Perspectives, Vol. 17, Summer.

Bebchuk, Lucian A., and Jesse M. Fried. 2004. Pay without Performance: The Unfulfilled Promise of Executive Compensation. Cambridge: Harvard University Press

Berle, Adolf A. and Gardiner C. Means. 1991. The Modern Corporation and Private Property. New Brunswick: Transaction Publishers.

Bertrand, Marianne, and Sendhil Mullainathan. 2001. “Are CEOs Rewarded for Luck? The Ones Without Principals Are.” Quarterly Journal of Economics 116(3): 901-32.

Bizjak, John M., Michael Lemmon, and Lalitha Naveen. 2008. "Does the Use of Peer Groups Contribute to Higher Pay and Less Efficient Compensation?,” Journal of Financial Economics, forthcoming.

Chandler, Alfred D. Jr. 1977. The Visible Hand. The Managerial Revolution in American Business. Massachusetts: The Belknap Press of Harvard University Press.

Cuñat, Vicente and Maria Guadalupe. 2004. "Executive Compensation and Competition in the Banking and Financial Sectors,” Working Paper.

Cuñat, Vicente and Maria Guadalupe. 2006. "Globalization and the Provision of Incentives Inside the Firm: The Effect of Foreign Competition,” Working Paper.

Fama, Eugene F. 1980. “Agency Problems and the Theory of the Firm.” Journal of Political Economy 88 (April): 288-307

Frydman, Carola. 2006. "Rising through the Ranks: The Evolution of the Market for Corporate Executives, 1936-2003,” Working Paper.

Frydman, Carola and Raven Saks. 2008. "Executive Compensation: A New View from a Long-Term Perspective, 1936-2005,” NBER Working Paper No. W14145.

Gabaix, Xavier and Agustin Landier. 2008. "Why Has CEO Pay Increased So Much?,” Quarterly Journal of Economics, 123(1): 49-100.

Gompers, Paul, Joy Ishii, and Andrew Metrick. 2003. “Corporate Governance and Equity Prices,” Quarterly Journal of Economics, Vol. 118(1): 107-155

Hall, Brian J. and Jeffrey B. Liebman. 1998. “Are CEOs Really Paid like Bureaucrats?” Quarterly Journal of Economics 113 (August): 653-691. 
Hermalin, Benjamin E. 2005. “Trends in Corporate Governance,” Journal of Finance 60: 2351-2384

Hubbard, R. Glenn and Darius Palia. 1995. "Executive Pay and Performance: Evidence from the U.S. Banking Industry,” Journal of Financial Economics Vol. 39 (1): 105130

Huson, Mark R., Robert Parrino and Laura T. Starks. 2001. “Internal Monitoring Mechanisms and CEO Turnover: A Long-Term Perspective.” Journal of Finance 56: 2265-2297.

Kaplan, Steven N. and Bernadette A. Minton. 2006. “How has CEO Turnover Changed? Increasingly Performance Sensitive Boards and Increasingly Uneasy CEOs,” NBER Working Paper No. W12465

Kaplan, Steven N. and Joshua Rauh. 2007. "Wall Street and Main Street: What Contributed to the Rise in the Highest Incomes?,” Working Paper

Khurana, Rakesh. 2002. Searching for a Corporate Savior. The Irrational Quest for Charismatic CEOs. New Jersey: Princeton University Press

Lehn, Kenneth, Sukesh Patro, and Mengxin Zhao. 2003. "Determinants of the Size and Structure of Corporate Boards: 1935-2000.” Working Paper.

Levy, Frank S. and Peter Temir. 2007. "Inequality and Institutions in $20^{\text {th }}$ Century America,” MIT Department of Economics Working Paper No. 07-17

Llense, Fabienne. 2008. "French CEO Compensations: What is the Cost of a Mandatory Upper Limit?,” Working Paper.

Murphy, Kevin J. 1999. “Executive Compensation.” In Handbook of Labor Economics, vol. 3B, edited by Orley Ashenfelter and David Card. Amsterdam, New York: North Holland.

Murphy, Kevin J. and Ján Zábojník. 2004. "CEO Pay and Turnover: A Market Based Explanation for Recent Trends." American Economic Review (Papers and Proceedings) 94: 192-196

Murphy, Kevin J. and Ján Zábojník. 2007. "Managerial Capital and the Market for CEOs,” Working Paper.

Packard, Vance. 1962. The Pyramid Climbers. New York: McGraw-Hill Book Company, Inc. 
Piketty, Thomas and Emmanuel Saez. 2003. "Income Inequality in the United States: 1913-1998.” Quarterly Journal of Economics 118: 1-39.

Rosen, Sherwin. 1981. "The Economics of Superstars,” American Economic Review 71: 845-858

Rosen, Sherwin. 1982. "Authority, Control and the Distribution of Earnings," Bell Journal of Economics 13: 311-323

Seligman, Joel. 2003. The Transformation of Wall Street. New York: Aspen Publishers.

Tervio, Marko. 2007. "The Difference That CEOs Make: An Assignment Model Approach,” Working Paper

Whyte, William H., Jr. 1956. The Organization Man. New York: Simon and Schuster 
Figure 1

The Real Level of Total Executive Compensation at General Electric

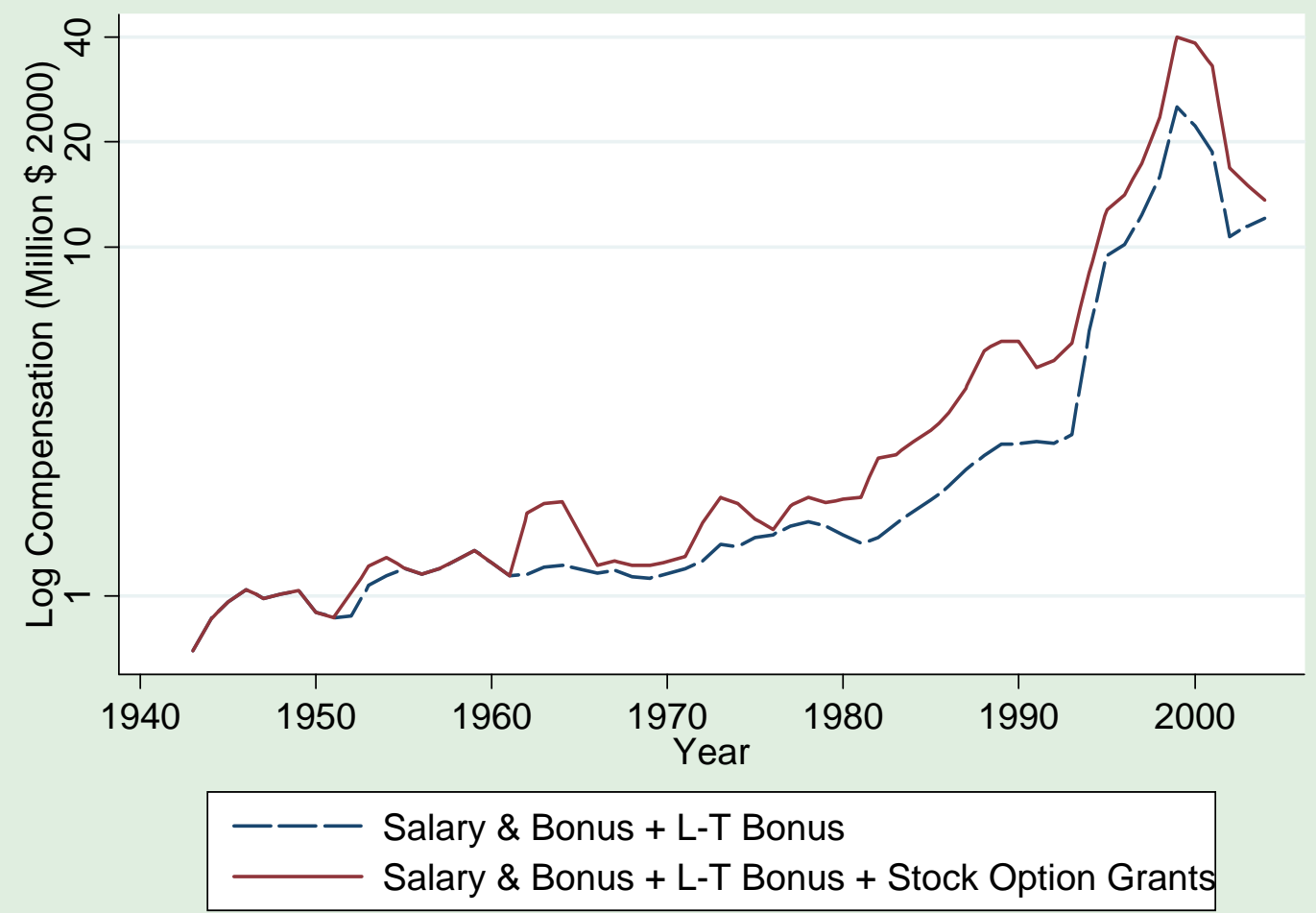

Notes: Compensation is measured as the three-year moving-average for each measure of pay for the three highest-paid executives as reported in General Electric's proxy statements. Salary and Bonus is defined as the level of salaries and current bonuses both awarded and paid out in the year. Long-Term (L-T) Bonus measures the amount paid out in the year from long-term bonuses awarded in prior years. Stock Option Grants is defined as the Black-Scholes value of stock options granted in the given year. The real level of pay is calculated in millions of $\$ 2000$, using the CPI. 


\section{CESifo Working Paper Series}

for full list see www.cesifo-group.org/wp

(address: Poschingerstr. 5, 81679 Munich, Germany, office@cesifo.de)

2397 Mohammad Reza Farzanegan, Illegal Trade in the Iranian Economy: Evidence from a Structural Model, September 2008

2398 Olivier Bos, Charity Auctions for the Happy Few, September 2008

2399 Robert S. Chirinko and Debdulal Mallick, The Marginal Product of Capital: A Persistent International Puzzle, September 2008

2400 Ben D'Exelle and Arno Riedl, Elite Capture, Political Voice and Exclusion from Aid: An Experimental Study, September 2008

2401 Torben M. Andersen and Joydeep Bhattacharya, On Myopia as Rationale for Social Security, September 2008

2402 Fabienne Llense, French CEO Compensations: What is the Cost of a Mandatory Upper Limit?, September 2008

2403 Valentina Bosetti, Carlo Carraro, Alessandra Sgobbi and Massimo Tavoni, Delayed Action and Uncertain Targets. How Much Will Climate Policy Cost?, September 2008

2404 Robert G. Chambers, Rolf Färe, Shawna Grosskopf and Michael Vardanyan, Generalized Quadratic Revenue Functions, September 2008

2405 Leonidas Enrique de la Rosa, Overconfidence in a Career-Concerns Setting, September 2008

2406 Marcus Drometer and Johannes Rincke, The Design of Political Institutions: Electoral Competition and the Choice of Ballot Access Restrictions in the United States, September 2008

2407 Markku Lanne and Helmut Lütkepohl, Stock Prices and Economic Fluctuations: A Markov Switching Structural Vector Autoregressive Analysis, September 2008

2408 Thomas L. Brewer, International Energy Technology Transfers for Climate Change Mitigations, September 2008

2409 Alexander Kemnitz, Native Welfare Losses from High Skilled Immigration, September 2008

2410 Xavier Vives, Strategic Supply Function Competition with Private Information, September 2008

2411 Fabio Padovano and Roberto Ricciuti, The Political Competition-Economic Performance Puzzle: Evidence from the OECD Countries and the Italian Regions, September 2008 
2412 Joan Costa-Font and Mireia Jofre-Bonet, Body Image and Food Disorders: Evidence from a Sample of European Women, September 2008

2413 Thorsten Upmann, Labour Unions - To Unite or to Separate?, October 2008

2414 Sascha O. Becker and Ludger Woessmann, Luther and the Girls: Religious Denomination and the Female Education Gap in $19^{\text {th }}$ Century Prussia, October 2008

2415 Florian Englmaier and Stephen Leider, Contractual and Organizational Structure with Reciprocal Agents, October 2008

2416 Vittorio Daniele and Ugo Marani, Organized Crime and Foreign Direct Investment: The Italian Case, October 2008

2417 Valentina Bosetti, Carlo Carraro, Alessandra Sgobbi and Massimo Tavoni, Modelling Economic Impacts of Alternative International Climate Policy Architectures. A Quantitative and Comparative Assessment of Architectures for Agreement, October 2008

2418 Paul De Grauwe, Animal Spirits and Monetary Policy, October 2008

2419 Guglielmo Maria Caporale, Christophe Rault, Robert Sova and Anamaria Sova, On the Bilateral Trade Effects of Free Trade Agreements between the EU-15 and the CEEC-4 Countries, October 2008

2420 Yin-Wong Cheung and Daniel Friedman, Speculative Attacks: A Laboratory Study in Continuous Time, October 2008

2421 Kamila Fialová and Ondřej Schneider, Labour Market Institutions and their Effect on Labour Market Performance in the New EU Member Countries, October 2008

2422 Alexander Ludwig and Michael Reiter, Sharing Demographic Risk - Who is Afraid of the Baby Bust?, October 2008

2423 Doina Maria Radulescu and Michael Stimmelmayr, The Welfare Loss from Differential Taxation of Sectors in Germany, October 2008

2424 Nikolaus Wolf, Was Germany ever United? Evidence from Intra- and International Trade 1885 - 1933, October 2008

2425 Bruno S. Frey, David A. Savage and Benno Torgler, Noblesse Oblige? Determinants of Survival in a Life and Death Situation, October 2008

2426 Giovanni Facchini, Peri Silva and Gerald Willmann, The Customs Union Issue: Why do we Observe so few of them?, October 2008

2427 Wido Geis, Silke Uebelmesser and Martin Werding, Why go to France or Germany, if you could as well go to the UK or the US? Selective Features of Immigration to four major OECD Countries, October 2008 
2428 Geeta Kingdon and Francis Teal, Teacher Unions, Teacher Pay and Student Performance in India: A Pupil Fixed Effects Approach, October 2008

2429 Andreas Haufler and Marco Runkel, Firms' Financial Choices and Thin Capitalization Rules under Corporate Tax Competition, October 2008

2430 Matz Dahlberg, Heléne Lundqvist and Eva Mörk, Intergovernmental Grants and Bureaucratic Power, October 2008

2431 Alfons J. Weichenrieder and Tina Klautke, Taxes and the Efficiency Costs of Capital Distortions, October 2008

2432 Andreas Knabe and Ronnie Schöb, Minimum Wage Incidence: The Case for Germany, October 2008

2433 Kurt R. Brekke and Odd Rune Straume, Pharmaceutical Patents: Incentives for R\&D or Marketing?, October 2008

2434 Scott Alan Carson, Geography, Insolation, and Institutional Change in $19^{\text {th }}$ Century African-American and White Stature in Southern States, October 2008

2435 Emilia Del Bono and Daniela Vuri, Job Mobility and the Gender Wage Gap in Italy, October 2008

2436 Marco Angrisani, Antonio Guarino, Steffen Huck and Nathan Larson, No-Trade in the Laboratory, October 2008

2437 Josse Delfgaauw and Robert Dur, Managerial Talent, Motivation, and Self-Selection into Public Management, October 2008

2438 Christian Bauer and Wolfgang Buchholz, How Changing Prudence and Risk Aversion Affect Optimal Saving, October 2008

2439 Erich Battistin, Clara Graziano and Bruno Parigi, Connections and Performance in Bankers' Turnover: Better Wed over the Mixen than over the Moor, October 2008

2440 Erkki Koskela and Panu Poutvaara, Flexible Outsourcing and the Impacts of Labour Taxation in European Welfare States, October 2008

2441 Marcelo Resende, Concentration and Market Size: Lower Bound Estimates for the Brazilian Industry, October 2008

2442 Giandomenico Piluso and Roberto Ricciuti, Fiscal Policy and the Banking System in Italy. Have Taxes, Public Spending and Banks been Procyclical in the Long-Run? October 2008

2443 Bruno S. Frey and Katja Rost, Do Rankings Reflect Research Quality?, October 2008

2444 Guglielmo Maria Caporale, Antoaneta Serguieva and Hao Wu, Financial Contagion: Evolutionary Optimisation of a Multinational Agent-Based Model, October 2008 
2445 Valentina Bosetti, Carlo Carraro and Massimo Tavoni, Delayed Participation of Developing Countries to Climate Agreements: Should Action in the EU and US be Postponed?, October 2008

2446 Alexander Kovalenkov and Xavier Vives, Competitive Rational Expectations Equilibria without Apology, November 2008

2447 Thiess Buettner and Fédéric Holm-Hadulla, Cities in Fiscal Equalization, November 2008

2448 Harry H. Kelejian and Ingmar R. Prucha, Specification and Estimation of Spatial Autoregressive Models with Autoregressive and Heteroskedastic Disturbances, November 2008

2449 Jan Bouckaert, Hans Degryse and Thomas Provoost, Enhancing Market Power by Reducing Switching Costs, November 2008

2450 Frank Heinemann, Escaping from a Combination of Liquidity Trap and Credit Crunch, November 2008

2451 Dan Anderberg, Optimal Policy and the Risk Properties of Human Capital Reconsidered, November 2008

2452 Christian Keuschnigg and Evelyn Ribi, Outsourcing, Unemployment and Welfare Policy, November 2008

2453 Bernd Theilen, Market Competition and Lower Tier Incentives, November 2008

2454 Ondřej Schneider, Voting in the European Union - Central Europe's Lost Voice, November 2008

2455 Oliver Lorz and Gerald Willmann, Enlargement versus Deepening: The Trade-off Facing Economic Unions, November 2008

2456 Alfons J. Weichenrieder and Helen Windischbauer, Thin-Capitalization Rules and Company Responses, Experience from German Legislation, November 2008

2457 Andreas Knabe and Steffen Rätzel, Scarring or Scaring? The Psychological Impact of Past Unemployment and Future Unemployment Risk, November 2008

2458 John Whalley and Sean Walsh, Bringing the Copenhagen Global Climate Change Negotiations to Conclusion, November 2008

2459 Daniel Mejía, The War on Illegal Drugs in Producer and Consumer Countries: A Simple Analytical Framework, November 2008

2460 Carola Frydman, Learning from the Past: Trends in Executive Compensation over the Twentieth Century, November 2008 